\title{
Aspartic Proteinases in the Digestive Tract of Marine Decapod Crustaceans
}

\author{
MARÍA DE LOS ANGELES NAVARRETE DEL TORO ${ }^{1}$ \\ FERNANDO GARCÍA-CARREÑO ${ }^{1 *}$, MANUEL DÍAZ LÓPEZ ${ }^{2}$, \\ LAURA CELIS-GUERRERO ${ }^{1}$, AND REINHARD SABOROWSKI ${ }^{3}$ \\ ${ }^{1}$ Centro de Investigaciones Biológicas del Noroeste (CIBNOR). P.O. Box 128 \\ La Paz, B.C.S. 23000, México \\ ${ }^{2}$ Biología Aplicada, Escuela Politécnica Superior, Edificio CITE-II-B, \\ Universidad de Almería (UAL), 04120-La Cañada, Almería, Spain \\ ${ }^{3}$ Biologische Anstalt Helgoland, Alfred Wegener Institute for Polar and Marine \\ Research (BAH-AWI), P.O. Box 180, 27483 Helgoland, Germany
}

\begin{abstract}
$A B S T R A C T$ Decapod crustaceans synthesize highly active proteolytic enzymes in the midgut gland and release at least a part of them into the stomach where they facilitate the first step in peptide hydrolysis. The most common proteinases in the gastric fluid characterized so far are serine proteinases, that is, trypsin and chymotrypsin. These enzymes show highest activities at neutral or slightly alkaline conditions. The presence of acid proteinases, as they prevail in vertebrates, has been discussed contradictorily yet in invertebrates. In this study, we show that acid aspartic proteinases appear in the gastric fluid of several decapods. Lobsters Homarus gammarus showed the highest activity with a maximum at $\mathrm{pH}$ 3. These activities were almost entirely inhibited by pepstatin A, which indicates a high share of aspartic proteinases. In other species (Panulirus interruptus, Cancer pagurus, Callinectes arcuatus and Callinectes bellicosus), proteolytic activities were present at acid conditions but were distinctly lower than in $H$. gammarus. Zymograms at $\mathrm{pH} 3$ showed in each of the studied species at least one, but mostly two-four bands of activity. The apparent molecular weight of the enzymes ranged from 17.8 to $38.6 \mathrm{kDa}$. Two distinct bands were identified which were inhibited by pepstatin A. Acid aspartic proteinases may play an important role in the process of extracellular digestion in decapod crustaceans. Activities were significantly higher in clawed lobster than in spiny lobster and three species of brachyurans. Therefore, it may be suggested that the expression of acid proteinases is favored in certain groups and reduced in others. J. Exp. Zool. 305A:645-654, 2006. (C) 2006 Wiley-Liss, Inc.
\end{abstract}

How to cite this article: Navarrete del Toro MDLA, García-Carreño F, Lopez MD, Celis-Guerrero L, Saborowski R. 2006. Aspartic proteinases in the digestive tract of Marine decapod crustaceans. J. Exp. Zool. 305A:[645-654].

Digestion of alimentary proteins and processing of endogenous proteins is one of the most ancient metabolic processes evolved (Neurath, '84). Highly active proteinases for efficient utilization of alimentary proteins have been reported in many marine species. Using fish meal as protein source, the apparent in vitro protein digestibility was similar in vertebrates and in invertebrates. Fishes such as gilbel carp showed a value of $91 \%$ (Yang et al., 2004), Atlantic salmon 85\%, seabass juveniles 90-96\% and European seabass 95\% (Kaushik et al., 2004). In crustaceans, such as the whiteleg shrimp Penaeus vannamei, the apparent in vitro digestibility of protein amounted to $84-87 \%$ (Ezquerra et al., '97) in mud crab Scylla serratus to 95-97\% (Catacutan et al., 2003) and in Penaeus monodon to 90\% (Sudaryono et al., '99).

Proteolytic enzymes in the digestive organs of crustaceans have been well documented and

Grant sponsor: Consejo Nacional de Ciencia y Tecnología (CONACyT); Grant sponsor: International Bureau (IB) of the German Federal Ministry for Science and Technology (BMBF); Grant number: MEX 00/001.

*Correspondence to: F. García-Carreño, Centro de Investigaciones Biológicas del Noroeste (CIBNOR). P.O. Box 129, La Paz, B.C.S. 23000, México. E-mail: fgarcia@cibnor.mx

Received 20 January 2006; Accepted 12 April 2006

Published online 20 June 2006 in Wiley InterScience (www. interscience.wiley.com). DOI: $10.1002 /$ jez.a.318. 
characterized (e.g., Dall and Moriarty, '83; Glass and Stark, '94: Jones et al., '97; Le Vay et al., 2001). Different from vertebrates, the entire process of digestion in decapods happens exclusively enzymatically. The digestive gland (or midgut gland) is the site of digestive enzymes production. F- and B-cells secrete enzymes which facilitate the intra-luminal digestion of chyme from the gastric chamber (Ceccaldi, '98; Guillaume and Ceccaldi, 2001). The digestive gland produces a wide range of proteolytic enzymes: endopeptidases such as trypsin, chymotrypsin and astacin, and exopeptidases such as carboxypeptidases and aminopeptidases. Due to their common origin, the same proteinases are present in gastric juice as well as in the midgut gland. Generally, the activities are higher in the gastric fluid than in the midgut gland tissue (Figueiredo et al., 2001; Celis-Guerrero et al., 2004).

Most of the digestive proteinases belong to the families of serine and metallo-proteinases. The contribution of cysteine proteinases in digestion has been raised by Degkwitz ('57) and, recently, their presence has been reported in some caridean shrimps (Teschke and Saborowski, 2005). Serine proteinases show highest activities at neutral or mild alkaline $\mathrm{pH}$, while cysteine proteinases are most active at slightly acidic conditions $(\mathrm{pH}$ 4.7-6.0) which prevail in the cardiac chamber of the stomach in most crustaceans (Vonk and Western, '84). The reason of the low $\mathrm{pH}$ is uncertain, yet. However, already early workers have suggested that it is caused by the presence of acid salts, such as mono-disodium phosphate, rather than the release of free acids (Jordan, '13).

In vertebrates, aspartic proteinases such as pepsin play important roles in protein digestion at low $\mathrm{pH}$. These enzymes, however, seem to be rare or missing in crustaceans (reviewed by Gildberg, '88). Since then, it has been believed that invertebrates do not possess aspartic peptidase activities because of the lack of codifying genes for pepsin. To our knowledge, no further research on acid invertebrate digestive proteinases has been reported and also the role of cathepsins $\mathrm{D}$ and $\mathrm{E}$ in the digestive process has not been finally clarified yet. Cathepsin D may have an extracellular function as a digestive enzyme in addition to the intracellular lysosomal function in many invertebrates. This is particularly true for crustaceans such as Astacus sp., Cancer sp. and Homarus sp. (reviewed by Vonk and Western, '84) and for insects such as cockroach, Blattella germanica (Arruda et al., '95) and mosquito, Aedes aegypti (Cho et al., '91; Cho and Raikhel, '92).

In this work, we analyzed a number of ecologically and economically important decapod crustaceans from Northwest Europe and Pacific America for the presence of acid proteinases in their digestive tract. The study was carried out using non-reduced electrophoresis (substrate-SDSPAGE), which allows for the simultaneous comparison of crude extracts and determination of the apparent molecular masses of the enzymes. Furthermore, the effects of inhibitors and $\mathrm{pH}$ were evaluated. The role of acid proteinases in the digestive process is discussed.

\section{MATERIAL AND METHODS}

\section{Origin of animals}

The study was carried out at facilities of Centro de Investigaciones Biológicas del Noroeste (CIBNOR, La Paz, BCS, México), the University of Almería (Almería, Spain) and at the marine station of the Alfred Wegener Institute for Polar and Marine Research (AWI, Helgoland, Germany). Five species of decapod crustaceans were studied. Three of them (Spiny lobster, Panulirus interruptus, and the Blue crabs Callinectes bellicosus and Callinectes arcuatus) were sampled of the Mexican Pacific coast and in the Gulf of California. Edible crabs, Cancer pagurus, were sampled in the German North Sea at Helgoland. European lobster, Homarus gammarus came from Bretany (France) and were obtained from a trader (CuxFish, Cuxhaven, Germany) (Table 1). Live

TABLE 1. Details on the species studied, origin and dates of sampling

\begin{tabular}{llllr}
\hline Species & Abbrev. & Infraorder/Family & Origin & Date of sampling \\
\hline Panulirus interuptus & P.i. & Achaelata/Palinuridae & Pacific, BCS, Mexico & Nov. 2003 \\
Homarus gammarus & H.g. & Astacidae/Nephropoidae & Bretany, France & Sep. 2004 \\
Cancer pagurus & C.p. & Brachyura/Cancridae & North Sea, Germany & Sep. 2002 \\
Calinectes arcuatus & C.a. & Brachyura/Portunidae & Gulf of California, BCS, Mexico & Jun. 2002 \\
Calinectes belicosus & C.b. & Brachyura/Portunidae & Gulf of California, BCS, Mexico & Jun. 2002 \\
\hline
\end{tabular}


organisms were taken to the lab and acclimatized for 1 week in 40-L aquarium tanks with running and aerated seawater at ambient temperatures of $22^{\circ} \mathrm{C}$ at CIBNOR (Mexico) and $18^{\circ} \mathrm{C}$ in the BAH-Ecolab at Helgoland (Germany). Animals were fed daily ad libitum with fish, shrimp or squid meat.

\section{Enzyme preparations}

Gastric juice was sampled with a disposable syringe which was equipped with a $5-10 \mathrm{~cm}$ long Teflon tube smaller in diameter than the oral cavity. The Teflon tube was carefully inserted into the stomach through the esophagus. Depending on the size of the animals, up to $2 \mathrm{ml}$ of gastric juice was obtained by gently drawing the syringe. Samples were taken $12 \mathrm{hr}$ after the last feeding. Each animal was treated only once. In total, 6-20 animals per species were sampled. Immediately after sampling, the $\mathrm{pH}$ of the gastric fluid was measured with a $\mathrm{pH}$ meter using a microelectrode. Then the gastric juices were transferred into $1.7 \mathrm{ml}$ microtubes and centrifuged for $10 \mathrm{~min}$ at $10,000 \mathrm{~g}$ and $4^{\circ} \mathrm{C}$ to separate solids. A small subsample of the supernatant was used for immediate enzyme activity measurements. The rest of the supernatants were lyophilized and subsequently stored at $-20^{\circ} \mathrm{C}$. Prior to enzyme evaluations, the powder was dissolved in cold distilled water $(1: 50 ; \mathrm{w} / \mathrm{v})$. The solution was centrifuged at $10,000 \mathrm{~g}$ and $4^{\circ} \mathrm{C}$ for $10 \mathrm{~min}$. The supernatants, always kept on ice, were subsequently used for enzyme assays or electrophoresis. The recovery of enzyme activities was checked for each species by comparing activities of the original supernatant measured immediately after sampling and activities of re-dissolved enzymes. The recovery amounted on average to $90 \%$.

\section{Protein quantification and enzyme activity assays}

Total soluble protein was evaluated with the Coomassie blue dye method according to Bradford ('76) using serum bovine albumin as the standard.

Acid proteinase activity at $\mathrm{pH} 3$ was assayed after the method originally described by Anson ('38) and modified by Celis-Guerrero et al. (2004) in a solution of $0.5 \%(\mathrm{w} / \mathrm{v})$ bovine hemoglobin (Sigma H-2625) in 0.1 M Glycine - $\mathrm{HCl}$ buffer. One milliliter of the substrate solution was mixed in a reaction tube with $10 \mu \mathrm{l}$ of enzyme preparation and incubated for $10 \mathrm{~min}$ at $25^{\circ} \mathrm{C}$. The reaction was stopped by adding $500 \mu \mathrm{l}$ of $20 \%(\mathrm{w} / \mathrm{v})$ trichloroacetic acid (TCA) and cooling on ice for $10 \mathrm{~min}$. The undigested substrate precipitated was separated by centrifugation for $5 \mathrm{~min}$ at $10,000 \mathrm{~g}$. The absorbance of the supernatants was measured spectrophotometrically at $280 \mathrm{~nm}$ against distilled water. Control assays (blanks) received TCA solution before the substrate was added.

Alkaline proteinase at $\mathrm{pH} 8$ was assayed as described above, however, with $1 \%(\mathrm{w} / \mathrm{v})$ of casein as substrate (Sigma C-5890) in $50 \mathrm{mM}$ Tris $\cdot \mathrm{HCl}$ buffer. Ten microliters of the enzyme preparation was mixed in a microtube with $0.5 \mathrm{ml}$ of $50 \mathrm{mM}$ Tris $\cdot \mathrm{HCl}$. Substrate solution $(500 \mu \mathrm{l})$ was added and the tube was incubated for $10 \mathrm{~min}$ at $25^{\circ} \mathrm{C}$. The reaction was stopped by the addition of $0.5 \mathrm{ml}$ of $20 \%$ TCA. Then the tubes were centrifuged for $5 \mathrm{~min}$ at $10,000 \mathrm{~g}$. The absorbance of the supernatants was recorded at $280 \mathrm{~nm}$ against distilled water. For the blanks, TCA solution was added before the substrate was supplied. Total protease units of activity were expressed as change in absorbance per minute per milligram of protein ( $U=\mathrm{Abs}_{280} \mathrm{~min}^{-1} \mathrm{mg}^{-1}$ protein).

\section{The effect of pH on enzyme activity}

The effect of $\mathrm{pH}$ on proteases was evaluated in the range between $\mathrm{pH} 2$ and 10 on pooled samples of three individuals. For $\mathrm{pH} 2-4$, hemoglobin $(0.5 \%$ in $100 \mathrm{mM}$ universal buffer) was used as substrate. Between pH 5 and 10, casein (1\% in universal buffer) was used as substrate (Stauffer, '89). The assays with both substrates were performed as described above for hemoglobin and casein.

\section{The effect of inhibitors on enzyme activity}

In order to evaluate the major classes of proteolytic enzymes, preparations were incubated with specific inhibitors (García-Carreño, '92). Pepstatin A (1 mM in dimethylsulfoxide, DMSO) was used to inhibit aspartic proteinases including cathepsin D-like and cathepsin E-like enzymes, $10 \mathrm{mM}$ TLCK (tosyl-lysine chloromethyl ketone) in $1 \mathrm{mM} \mathrm{HCl}$ to inhibit trypsin and cysteine activity, and $1 \mathrm{mM}$ E-64 in DMSO to inhibit cysteine proteinases including cathepsin B-like and cathepsin L-like proteinases. Aliquots of $10 \mu \mathrm{l}$ of each inhibitor stock solution were mixed separately with $10 \mu$ l enzyme extracts and subsequently incubated for $60 \mathrm{~min}$ at $25^{\circ} \mathrm{C}$. Thereafter, the samples which were treated with the inhibitors were assayed for activity at $\mathrm{pH} 3$ as described above for total proteinase. Assays were run in 
triplicate. Control assays contained inhibitor solvent without the inhibitor. Residual activity was calculated in relation to uninhibited activity.

In order to identify the molecular mass, class and family of proteases, enzyme samples were incubated with specific inhibitors after the method of García-Carreño and Haard ('93). Zymograms with and without inhibitors were run and analyzed for the presence or absence of activity bands.

\section{SDS-PAGE and substrate SDS-PAGE}

Proteins and enzymes present in the preparations were separated by $14 \%$ SDS-PAGE according to Laemmli ('70). Enzyme preparations were mixed with sample treatment buffer (1:2) but were neither boiled nor treated with mercaptoethanol. Fifteen microliters of samples (on average $100 \mu \mathrm{g}$ protein) and $4 \mu \mathrm{l}$ of low-molecular-mass standards (Pharmacia, 17-0446-01) were loaded into individual gel slots in a vertical electrophoresis device (Hoeffer SE260, gel size $8 \times 10 \mathrm{~cm})$ and were run at $4^{\circ} \mathrm{C}$ at maximum $15 \mathrm{~mA}$ per gel. After electrophoresis, gels were stained with 0.05\% Coomassie Brillant Blue R-250 in an aqueous solution of $40 \%$ methanol and $7 \%$ acetic acid for at least $4 \mathrm{hr}$ and then distained with the same solution without dye.

The composition of endopeptidases was evaluated by substrate-SDS-PAGE (García-Carreño et al., '93). For acidic proteinase activity, gels were immersed after electrophoresis in $1 \mathrm{mM} \mathrm{HCl}$ solution for $5 \mathrm{~min}$ several times until the bromophenol blue dye front changed to yellow. Then the gels were immersed in $100 \mathrm{mM}$ Glycine $\cdot \mathrm{HCl} \mathrm{pH}$ 3 for $10 \mathrm{~min}$. Then the gels were transferred to a tray containing $100 \mathrm{ml}$ of $0.25 \%(\mathrm{w} / \mathrm{v})$ hemoglobin in $100 \mathrm{mM}$ Glycine - $\mathrm{HCl}$ buffer $\mathrm{pH}$ 3. The tray was placed in an ice bath and remained there for 30 min under slow speed in an orbital shaker to allow the substrate to penetrate into the gels. Then the temperature was raised to $25^{\circ} \mathrm{C}$ and the gel was incubated for another $90 \mathrm{~min}$. The gels were thoroughly washed with distilled water and then were stained and distained as described above. For alkaline protease activity $3 \%(\mathrm{w} / \mathrm{v})$ casein in $50 \mathrm{mM}$ Tris $-\mathrm{HCl}, \mathrm{pH} 8.0$ was used as the substrate while the procedure remained the same as described above. Activity band appeared pale on an otherwise blue dyed background.

\section{Statistical analysis}

Data were expressed as mean \pm standard error of the mean (SEM). Differences among means were analyzed by ANOVA followed by a Tukey's multi-comparison test. Differences are reported as statistically significant when $P<0.05$ (Zar, '84). Statistical differences of data sets in tables and graphs are indicated by different letters. Statistical analysis was carried out with the computer program SigmaStat 2.03 (SPSS Inc.).

\section{RESULTS}

\section{pH of gastric juice (Table 2)}

The gastric juices of all species studied here were different in color ranging from dark olive over brownish to reddish or dark yellow. The appearance of colors was not related to species, nor gender, size or $\mathrm{pH}$. In all species, the $\mathrm{pH}$ of the gastric juices was slightly acidic ranging from 4.7 in $H$. gammarus to 6.1 in C. arcuatus. The $\mathrm{pH}$ of the gastric juice of $H$. gammarus was significantly lower than the gastric $\mathrm{pH}$ values of all other species.

\section{Total proteolytic activity (Fig. 1a and b)}

Enzyme preparations from all species hydrolyzed casein at $\mathrm{pH} 8$ showing activities from $1.53 \pm 0.21 \mathrm{Abs}_{280} \mathrm{~min}^{-1} \mathrm{mg}_{\mathrm{prt}}^{-1}$ in $C$. pagurus to $2.51 \pm 0.06 \mathrm{Abs}_{280} \mathrm{~min}^{-1} \mathrm{mg}_{\mathrm{prt}}^{-1}$ in $P$. interuptus (Fig. 1b). Casein digestion in $H$. gammarus amounted to $0.16 \pm 0.04 \mathrm{Umg}_{\mathrm{prt}}^{-1}$ and was significantly lower than in all other species.

TABLE 2. $p H$ values and the protein content of the gastric juice of decapods (means $\pm S E M$ )

\begin{tabular}{lcrc}
\hline Species & $\mathrm{pH}$ of gastric juice & $(n)$ & ${\text { Proteins }\left(\mathrm{mg} \mathrm{ml}^{-1}\right)^{1}}^{(n)}$ \\
\hline Palinurus interruptus & $6.0 \pm 0.06$ & 15 & $11.9 \pm 0.44$ \\
Homarus gammarus & $4.7 \pm 0.02$ & 5 & $6.71 \pm 0.52$ \\
Cancer pagurus & $5.8 \pm 0.3$ & 8 & $7.40 \pm 2.92$ \\
Callinectes arcuatus & $6.1 \pm 0.24$ & 6 & $7.96 \pm 1.81$ \\
Callinectes bellicosus & n.d. & & $6.11 \pm 1.82$ \\
\hline
\end{tabular}

${ }^{1}$ Values obtained from solubilized freeze-dried samples $(50 \mathrm{mg}$ of dry sample in $1 \mathrm{~mL}$ of water), 

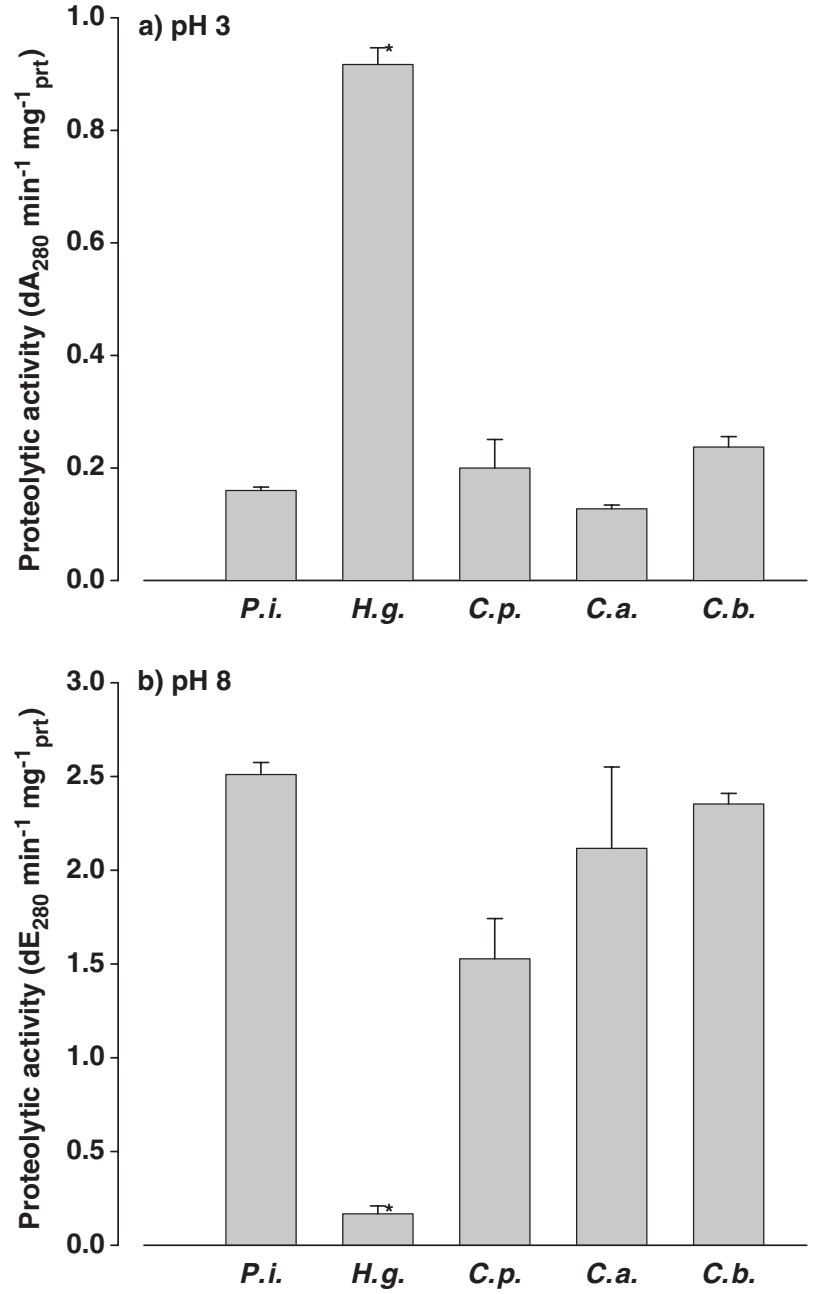

Fig. 1. Activities of (a) acid proteinase at $\mathrm{pH} 3$ and (b) alkaline proteinases at $\mathrm{pH} 8$ of decapod crustaceans. Means \pm SEM, $n=3-5$. Significantly different values $(P<0.001)$ are indicated by asterisks.

Total proteolytic activity of gastric juices at $\mathrm{pH} 3$ using hemoglobin (Fig. 1a) as the substrate was highest in $H$. gammarus $0.92 \pm 0.05 \mathrm{U} \mathrm{mg}_{\text {prt }}^{-1}$, followed by $C$. bellicosus $0.24 \pm 0.03 \mathrm{U} \mathrm{mg}_{\mathrm{prt}}^{-1}$, C. pagurus $0.20 \pm 0.08 \mathrm{U} \mathrm{mg}_{\mathrm{prt}}^{-1}, P$. interuptus $0.16 \pm$ $0.006 \mathrm{U} \mathrm{mg}_{\mathrm{prt}}^{-1}$ and $C$. arcuatus $0.13 \pm 0.01 \mathrm{U} \mathrm{mg}_{\mathrm{prt}}^{-1}$ (Fig. 1a).

\section{The effect of $\mathrm{pH}$ on proteolytic activity}

(Fig. 2a-e)

The effect of $\mathrm{pH}$ on the total proteolytic activity was assayed by hemoglobin and casein digestion (Fig. 2). P. interruptus had maximum activity at $\mathrm{pH} 7$, showing lowest activities at acid $\mathrm{pH}$ but still elevated values at alkaline condition above $\mathrm{pH} 7$ (Fig. 2a). In $H$. gammarus the proteolytic activity was highest at $\mathrm{pH} 3$ (Fig. 2b). A second but lower maximum of activity appeared at $\mathrm{pH}$ 6. Different to $P$. interruptus, activities rapidly decreased when the $\mathrm{pH}$ further increased. All of the brachyuran species showed maximum activities between $\mathrm{pH} 6$ and 8 (Fig. 2c-e). In C. pagurus, maximum activity appeared at $\mathrm{pH} 7$. At $\mathrm{pH} 5$ the activity amounted to less than $50 \%$ of the maximum (Fig. 2c). In both species of Callinectes, proteolytic activities were lower at acid $\mathrm{pH}$ than at alkaline $\mathrm{pH}$ (Fig. 2d). Broad maxima of activity were present between $\mathrm{pH} 6$ and 8 in C. arcuatus (Fig. 2d) and between $\mathrm{pH} 6$ and 9 in C. bellicosus (Fig. 2e). The activity remained high above $\mathrm{pH} 9$ showing more than $75 \%$ of the maximum activity.

\section{Effects of inhibitors on proteolytic activity (Fig. 3)}

The effect of inhibitors on proteolytic activities in gastric juices of decapods was evaluated at $\mathrm{pH} 3$. In $H$. gammarus, the proteolytic activity was entirely abolished by pepstatin A. In P. interruptus, pepstatin A reduced proteolytic activity to one third of the control. In the brachyuran species the inhibitory effect of pepstatin A was less distinct. The resulting activities amounted to $45 \%$ in $C$. arcuatus and to $66 \%$ in C. pagurus. Different to papstatin $\mathrm{A}$, the effect of trypsin and cysteine inhibitor TLCK was uniform in all species, resulting in residual activities of 68-77\%. E-64 inhibited significantly the proteolytic activity in $H$. gammarus $(21 \%)$ and in C. arcuatus (38\%). No significant inhibition was observed in $P$. interruptus, C. pagurus and C. bellicosus.

\section{Zymograms at pH 8 and 3 (Fig. 4)}

Each species expressed an individual pattern of proteolytic enzyme activities at pH 3 (Fig. 4a) and at $\mathrm{pH} 8$ (Fig. $4 \mathrm{~b}$ ). P. interruptus showed at $\mathrm{pH} 8$ ten activity bands of apparently $66-16.2 \mathrm{kDa}$. The highest activity band was of $21.4 \mathrm{kDa}$. However, at $\mathrm{pH} 3$ no activity of these proteins was detected. Two bands around 25.7 and $20 \mathrm{kDa}$ showed activities at both pHs. $H$. gammarus showed one band of activity at $20 \mathrm{kDa}$ at $\mathrm{pH} 8$. At $\mathrm{pH} 3$, the same sample showed four activity bands, the highest at 30.2 and $17.8 \mathrm{kDa}$. C. pagurus had several bands around $75.0-20.4 \mathrm{kDa}$ of proteolytic activity at $\mathrm{pH} 8$. One band of 52.5 showed the highest activity. However, at $\mathrm{pH} 3$ only very low proteolytic activities were observed at 36.7 and $26.1 \mathrm{kDa}$. Both Callinectes species had several bands of activity at $\mathrm{pH} 8$, those of $C$. arcuatus around $53.7-23.4 \mathrm{kDa}$ and those of $C$. bellicosus at 

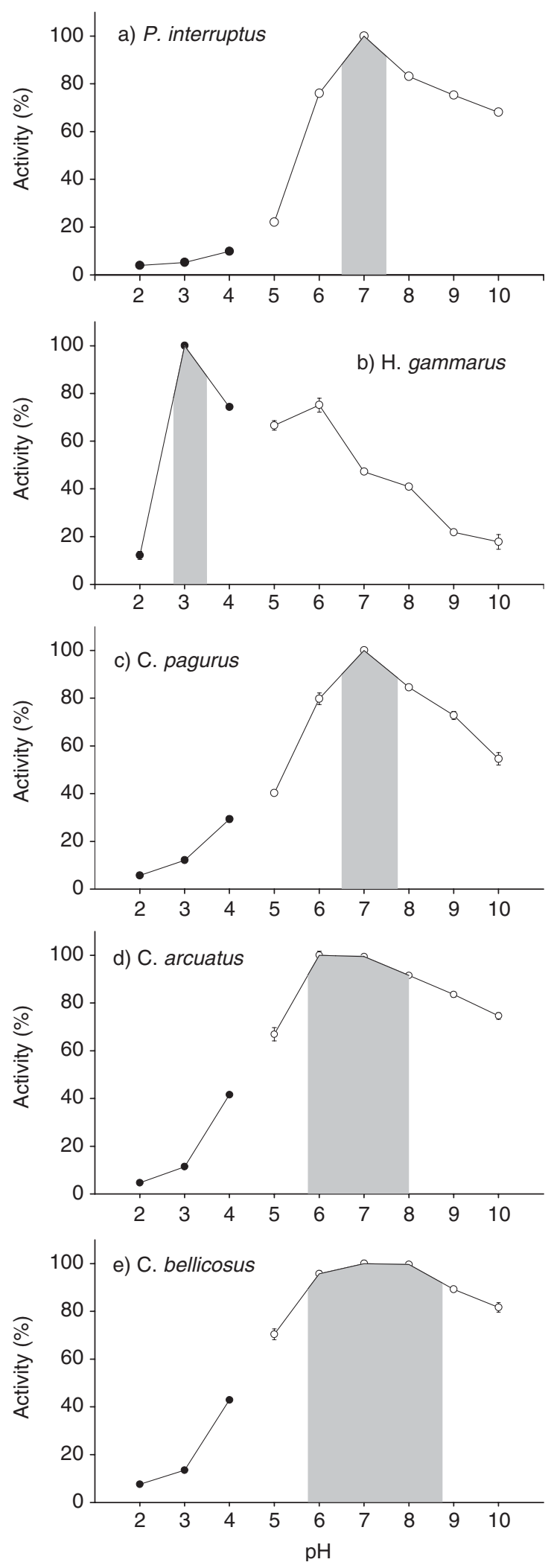

51.0-23.6 kDa. At $\mathrm{pH} 3$, crabs showed four activity bands between 35.6 and $24.3 \mathrm{kDa}$.

\section{Effects of inhibitors on activity displayed in zymograms (Fig. 5)}

Gastric juice from $H$. gammarus was incubated prior to electrophoresis with specific inhibitors. The zymogram at $\mathrm{pH} 3$ showed two bands of activity which were inhibited by pepstatin A. TLCK and E-64 did not affect the activities of both enzymes. The apparent sizes of the proteins were 30.2 and $17.8 \mathrm{kDa}$.

\section{DISCUSSION}

The presence of proteolytic enzymes active at acid $\mathrm{pHs}$ in digestive systems of invertebrates was discussed by Gildberg ('88) and eventually neglected in more recent studies. Our data, however, strongly support the presence of aspartic proteolytic enzymes in the gastric juice of decapods and, thus, indicate a potential role in the digestion of alimentary proteins.

Some of the most intensively investigated and, probably, most important digestive enzymes present in crustaceans may be those of the serine proteases family showing highest activities at neutral or slightly alkaline conditions (Dall and Moriarty, '83, Ceccaldi, '98). They are characterized by an active site consisting of histidine, aspartate and serine as the nucleophilic residue to attack the scissile peptide bond in proteins. In several previous studies, we found that not the entire proteolytic activities in the gastric juice of crustaceans could be assigned to serine proteinases, either because total activity was not entirely inhibited by specific inhibitors or because significant activity was detected at acid $\mathrm{pH}$ (García-Carreño et al., 2003; Celis-Guerrero et al., 2004).

Besides serine proteinases, also proteolytic enzymes belonging to the cysteine proteinase family have been identified in crustaceans (Le Boulay et al., '95). The nuclophile in the catalytic site of cysteine proteinases is formed by the sulfhydryl group of a Cys residue, active at slightly acidic and

Fig. 2. The effect of $\mathrm{pH}$ on the activities of proteolytic enzymes from the gastric juices of crustaceans. The substrates used were hemoglobin ( $\mathrm{pH}$ 2-4) and casein ( $\mathrm{pH} 5-10)$. Shaded areas emphasize the $\mathrm{pH}$ ranges of highest activities. Activity calculations are based on the absorption of digested substrate at $280 \mathrm{~nm}$ (means of pooled samples from three animals. $n=3$, SEM was less than $3 \%$ of the mean). 


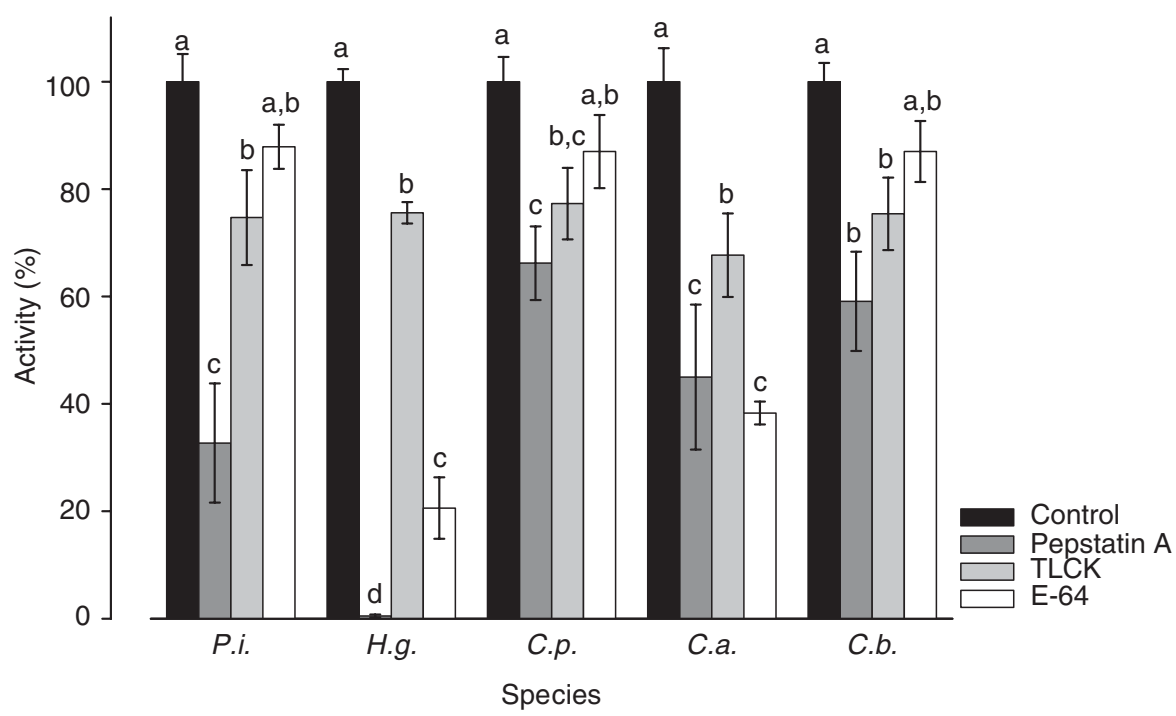

Fig. 3. The effect of inhibitors on the activities of proteolytic enzymes from the gastric juice of crustaceans. The activities were calculated in relation to a control assay which was not treated with any inhibitor (means \pm SEM, $n=6$ animals).
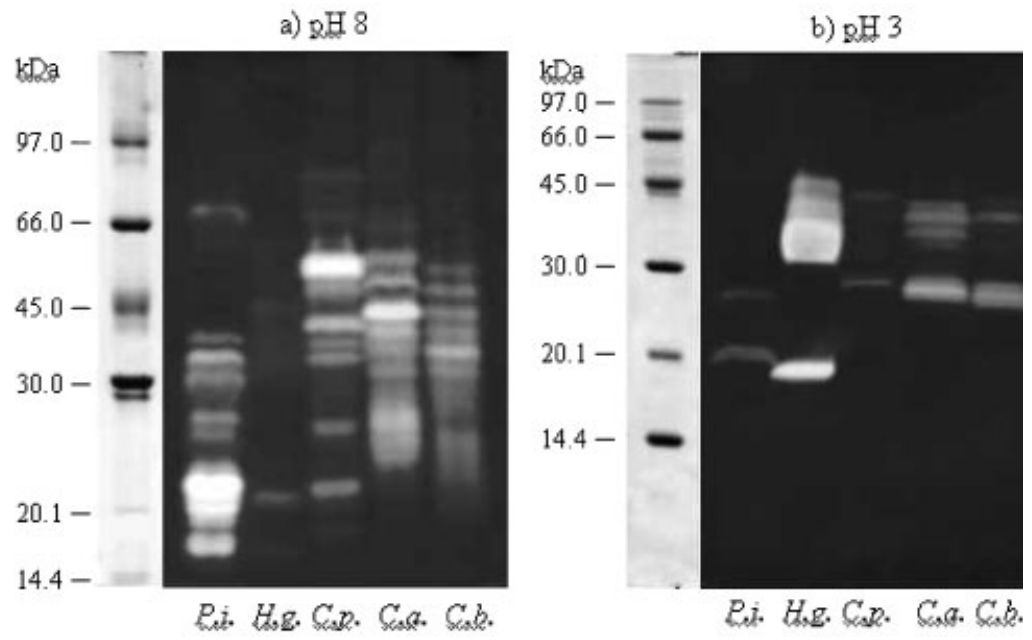

Fig. 4. Zymograms at $\mathrm{pH}$ 8. : (a) performed with casein as substrate. At pH 3 (b) hemoglobin was used as substrate. The amounts of protein applied to the gels were: $135 \mu \mathrm{g}$ (P.i.), $68 \mu \mathrm{g}$ (H.g.), $56 \mu \mathrm{g}$ (C.p.), $80 \mu \mathrm{g}$ (C.a.) and $80 \mu \mathrm{g}($ C.b.).

neutral $\mathrm{pH}$. They have been isolated from a wide range of sources with several physiological roles, generally involved in intracellular lysosomal processes. Cysteine proteinases seem also to be involved in food digestion in invertebrates. For example, in the digestive fluid of the American lobster, Homarus americanus, a cysteine proteinase accounts for $80 \%$ of the proteolytic activity (Laycock et al., '89, '91) and in North Sea shrimps, Crangon sp. for 70\% (Teschke and Saborowski, 2005). Cysteine proteinases were also present in the species studied here showing highest shares in H. gammarus and C. arcuatus. Particularly, our results on lobsters are in good agreement with the data presented previously by Laycock et al. ('89). Some cysteine proteinases have been identified as cathepsins. In the shrimp, Pandalus borealis, cathepsin B is transcribed exclusively in the digestive gland, suggesting a significant role as digestive enzyme (Aoki et al., 2003). A cathepsin $\mathrm{L}$ was isolated from the stomach of Norway lobster, Nephrops norvegicus (Le Boulay et al., '95) and was also identified in the digestive gland of shrimp, Metapenaeus ensis (Hu and Leung, 2004). 


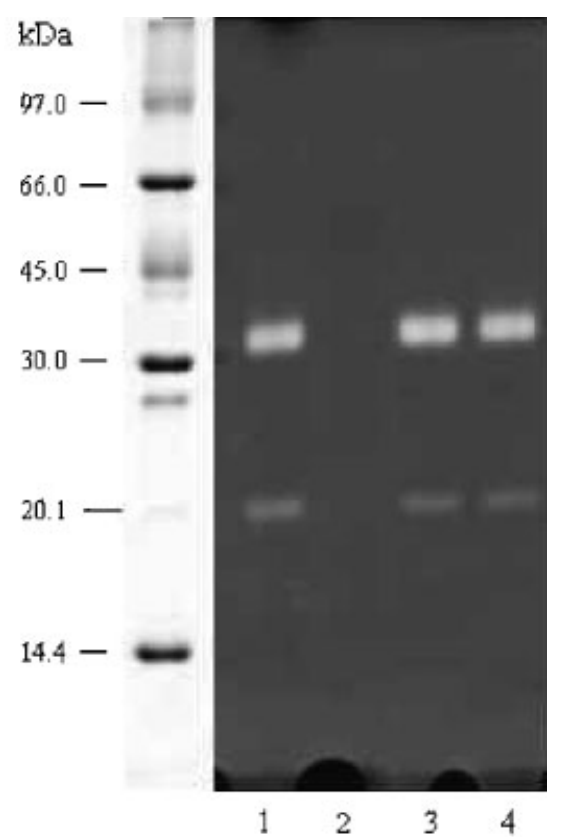

Fig. 5. Zymogram of endopeptidases from the gastric juice of $H$. gammarus.: Lanes: (1) Marker, (2) Control, (3) Pepstatin A, (4) TLCK, (5) E-64. The amount of protein applied was $18 \mu \mathrm{g}$.

Aspartic proteases, as they appear in the gastric juices of vertebrates, are active even at $\mathrm{pH}$ as low as 3 . These enzymes are a class of endopeptidases in which the nucleophile that attacks the scissile peptide bond is an activated water molecule rather than the nucleophilic side chain of an amino acid. Aspartic residues of the active site are involved in catalysis, working as ligands of the activated water molecule. They are active in acidic $\mathrm{pH}$ and are inhibited reversibly by pepstatin $\mathrm{A}$ and irreversibly by a variety of diazoacetyl compounds in the presence of $\mathrm{Cu}^{2+}$.

The most common technique to identify enzymes in crude extracts is to challenge the enzymes with specific substrates and inhibitors and to evaluate their activities. However, a problem arises in the case of aspartic peptidases. Although some inhibitors are quite sensitive, they often lack enough specificity for the class or type of enzyme due to their often similar tertiary structures. All enzymes belonging to the aspartic peptidase family $A$, such as pepsin, cathepsin D and cathepsin $\mathrm{E}$, are bilobed molecules with the active site between the lobes. They can accommodate a relatively broad range of substrate residues in the $\mathrm{P} 1-\mathrm{P} 1^{\prime}$ positions. Therefore, further analytical procedures are required to distinguish between them (Barrett et al., '98).
We propose four explanations for the presence of aspartic proteases in the digestive system of crustaceans. (1) These enzymes are vestigial ones. They remained in the organisms with limited function during evolution. (2) These enzymes contribute to the hydrolysis of food protein as fully operational enzymes by keeping some activity at acid pH. (3) That all or at least most such enzymes may contribute to the activity by keeping some activity at acid $\mathrm{pH}$. (4) Aspartic proteases isolated from the gastric juice were introduced with food or are gastric flora-born.

Premise (3) was discarded because the pattern of activity bands differed in all species distinctly between $\mathrm{pH} 3$ and $\mathrm{pH} 8$. Accordingly, not the same proteins showed activities at both $\mathrm{pHs}$ and, thus, the contribution of aspartic proteinases to proteolytic activity at acid $\mathrm{pH}$ seems to be limited to specific enzymes rater than to a broad majority of them.

Premise (4) was also discarded when we evaluated food. No evidence of the presence of such enzymes in food was found by test tube or substrate-SDS-PAGE (data not shown), and no evidence of a significant contribution of enzymes from bacteria was found, which agrees with previous studies by Donachie et al. ('95) on gastric bacteria in krill.

Finally, it is the presence of aspartic proteolytic enzymes of some use for digestion of food protein or is it just a vestigial character? Both possibilities are likely. Vestigial enzymes are not uncommon. Pepsin B has a weak general proteolytic activity, about 4\% of that of pepsin A (Barrett et al., '98), and does not contribute much in digestion. However, in all of the organisms studied in the present work, enzyme activity at $\mathrm{pH} 3-5$ was significant and Pepstatin A significantly inhibited the total activity at $\mathrm{pH} 3$.

Synthesis of mRNAs for trypsin, amylase, chitinase and cathepsin-L happens in the F-cells of the epithelium lining of the digestive gland tubules in P. monodon (Lehnert and Johnson, 2002). Since the secretion of digestive enzymes is holocrine (Ceccaldi, '97), it is possible that, beside digestive enzymes, any compartments and, thus, enzymes from the cell may be secreted to the lumen of the midgut gland tubules. The fluid of the digestive gland enters the proventriculus where it is mixed with ingested food to initiate the first steps of digestion. Accordingly, it seems not exceptional finding enzymes in the gastric juice including those having higher activity at acid $\mathrm{pH}$. 
Decapod species exhibit a great variety in the composition of proteolytic activities, both quantitatively and qualitatively (García-Carreño and Haard, '93; García-Carreño et al., '93). On the first sight, no homogeneous pattern in the expression of digestive enzymes seems to exist. However, comparative studies showed similarities in the expression of proteinases classes in species from different phylogenetic branches (Teschke and Saborowski, '05; Saborowski, pers. com.) and, thus, may reflect evolutionary traits in proteinase expression within the decapods.

A discussion on this topic, however, raises immediately a number of unsolved questions. If ancient enzymes are considered to perform most "simple" or most "basic" reactions, then serine proteinases, such as trypsins-like enzymes may be called ancient (Pfleiderer and Zwilling, '72; Neurath, '84). They show a highly conservative molecular structure, act in the extra-cellular space and catalyze the first steps in proteolysis at an optimum $\mathrm{pH}$ similar to that of seawater. They already appeared with high activities in "ancient" species such as brine shrimp, Artemia sp. (Ezquieta and Vallejo, '85; Pan et al., '91) or the branchiopod Triops sp. (Maeda-Martínez et al., 2000). On the contrary, more modern proteinases should show properties derived from the ancient ones. These may comprise complex reaction mechanisms, altered conditions for optimum catalysis (i.e., $\mathrm{pH})$ and/or compartmentalization. These properties seem better to apply for cysteine proteinases and aspartic proteinases, rather than for serine proteinases. These suggestions are in accordance with the hypothesized evolutionary pattern of acid proteinases by Gildberg ('88). The author suggested that aspartic proteinases may have evolved from a common ancestor similar to cathepsin D which progressed to pepsins in the acid stomachs of fish and finally, in the even more acid stomachs of vertebrates. However, the presumably most progressed proteinases do not inevitably appear in the morphologically most evolved crustacean taxa. The "ancient" serine proteinases are present in primitive groups such as palinurids. But they are also frequent and often even dominate in the gastric tracts of brachyurans, which represent the most modern crustaceans. On the contrary, presumably "modern" aspartic and cysteine proteinases appear in primitive groups such as lobsters, but are lacking in brachyurans. This apparent conflict cannot be resolved without additional information on the enzyme compo- sition of crustacean species from the major phylogenetic groups.

In conclusion, our work has shown that acid aspartic proteinases seem to play an important role in the process of extracellular digestion in decapod crustaceans. Since activities were significantly higher in clawed lobster than in spiny lobster and three species of brachyurans, it may be suggested that the expression of acid proteinases is favored in certain groups and reduced in others. Again, additional systematic studies are required.

\section{ACKNOWLEDGMENTS}

We greatly acknowledge the practical help of our colleagues from the participating institutions (BAH-AWI, CIBNOR, UAL) and the critical comments on the manuscript by Ira Fogel (CIBNOR). This research was supported by the Consejo Nacional de Ciencia y Tecnología (CONACyT) in Mexico and by the international Bureau (IB) of the German Federal Ministry for Science and Technology (BMBF) within the frame of the GermanMexican Science and Technology Cooperation Agreement under project no. MEX 00/001.

\section{LITERATURE CITED}

Anson ML. 1938. The estimation of pepsin, trypsin, papain and cathepsin with hemoglobin. J Gen Physiol 22:79-89.

Aoki H, Ahsan MdN, Watabe S. 2003. Molecular cloning and characterization of cathepsin B from the hepatopancreas of northern shrimp Pandalus borealis. Comp Biochem Physiol 134B:681-694.

Arruda LK, Vailes LD, Mann BJ, Shannon J, Fox JW, Vedvick TS, Hayden ML, Chapman MD. 1995. Molecular cloning of a major cockroach (Blattella germanica) allergen, Bla g 2. J Biol Chem 270:19563-19568.

Barrett AJ, Rawlings ND, Woessner JF. 1998. Handbook of proteolytic enzymes. San Diego: Academic Press.

Bradford MM. 1976. A rapid and sensitive method for the quantitation of microgram quantities of protein utilizing the principle of protein-dye binding. Anal Biochem 72:248-254.

Catacutan MR, Eusebio PS, Teshima S. 2003. Apparent digestibility of selected feedstuffs by mud crab, Scylla serrata. Aquaculture 216:253-261.

Ceccaldi HJ. 1997. Anatomy and physiology of the digestive system. In: D'Abramo LR, Conklin DE, Akiyama DM, editors. Crustacean nutrition. Baton Rouge, LA: The World Aquaculuture Society. p 261-291.

Ceccaldi HJ. 1998. A synopsis of the morphology and physiology of the digestive system of some crustacean species studied in France. Rev Fish Sci 6:13-39.

Celis-Guerrero LE, García Carreño FL, Navarrete del Toro MA. 2004. Characterization of proteases in the digestive system of Spiny Lobster (Panulirus interruptus). Mar Biotechnol 6:262-269.

Cho WL, Raikhel AS. 1992. Cloning of cDNA for mosquito lysosomal aspartic protease. Sequence analysis of an insect 
lysosomal enzyme similar to cathepsins D and E. J Biol Chem 267:21823-21829.

Cho WL, Dhadialla TS, Raikhel AS. 1991. Purification and characterization of a lysosomal aspartic protease with cathepsin D activity from the mosquito. Insect Biochem 21: 165-176.

Dall W, Moriarty DJW. 1983. Functional aspects of nutrition and digestion. In: Mantel LH, editor. The biology of Crustaceans, Vol. 5. Internal anatomy and physiological regulation. New York: Academic Press. p 215-261.

Degkwitz E. 1957. ein beitrag zur Natur der proteolytischen Verdauungsfermente bei verschiedenen Crustaceenarten. Veröffentl Inst Meeresf Bremerhaven 5:1-13.

Donachie SP, Saborowski R, Peters G, Buchholz F. 1995. Bacterial digestive enzyme activity in the stomach and hepatopancreas of Meganyctiphanes norvegica (M. Sars, 1857). J Exp Mar Biol Ecol 188:151-165.

Ezquieta B, Vallejo C. 1985. The trypsin like proteinase of Artemia: yolk localization and developmental activation. Comp Biochem Physiol 82B:731-736.

Ezquerra JM, García-Carreño FL, Civera R, Haard NF. 1997. $\mathrm{pH}$-stat method to predict protein digestibility in white shrimp (Penaeus vannamei). Aquaculture 157: 251-262.

Figueiredo MSRB, Kricker JA, Anderson AJ. 2001. Digestive enzyme activities in the alimentary tract of redclaw crayfish, Cherax quadricarinatus (Decapoda: Parastacidae). J Crustacean Biol 21:334-344.

García-Carreño FL. 1992. Protease inhibition in theory and practice. Biotechnol Educ 3:145-150.

García-Carreño FL, Haard NF. 1993. Characterization of proteinase classes in langostilla (Pleuroncodes planipes) and crayfish (Pacifastacus astacus) extracts. J Food Biochem 17: 97-113.

García-Carreño FL, Dimes LE, Haard NF. 1993. Substrate-Gel Electrophoresis for composition and molecular weight of proteinases or proteinaceous proteinase inhibitors. Anal Biochem 214:65-69.

García-Carreño F, Serviere-Zaragoza E, Navarrete del Toro M. 2003. Protein digestion in green abalone Haliotis fulgens Philippi, fed on natural foods. Comp Biochem Physiol 134B:143-150.

Gildberg A. 1988. Aspartic proteinases in fishes and aquatic invertebrates. Comp Biochem Physiol 91B:425-435.

Glass HJ, Stark JR. 1994. Protein digestion in the European lobster, Homarus gammarus (L.). Comp Biochem Physiol 108b:225-235.

Guillaume J, Ceccaldi HJ. 2001. Digestive physiology of shrimps. In: Guillaume J, Kaushik S, Bergot P, Métailler R, editors. Nutrition and feeding of fish and crustaceans. Chichester, UK: Springer-Praxis Publishing. p 239-252.

Hu KJ, Leung PC. 2004. Shrimp cathepsin L encoded by an intronless gene has predominant expression in hepatopancreas, and occurs in the nucleus of oocyte. Comp Biochem Physiol 137B:21-33.

Jones DA, Kumlu M, Le Vay L, Fletcher DJ. 1997. The digestive physiology of herbivorous, omnivorous and carnivorous crustacean larvae: a review. Aquaculture 155: 285-295.

Jordan H. 1913. Vergleichende Physiologie Wirbelloser Tiere. Erster Band. Die Ernährung. Jena: Fischer Verlag. 738p.
Kaushik SJ, Coves D, Dutto G, Blanc D. 2004. Almost total replacement of fish meal by plant protein sources in the diet of a marine teleost, the European seabass, Dicentrarchus labrax. Aquaculture 230:391-404.

Laemmli UK. 1970. Cleavage of structural proteins during the assembly of the head of bacteriophage T4. Nature 227: $680-685$.

Laycock MV, Hirama T, Hasnain S, Watson D, Storer AC. 1989. Purification and characterization of a digestive cysteine proteinase from the American lobster (Homarus americanus). Biochem J 263:439-444.

Laycock MV, MacKay RM, Di Fruscio M, Gallant JW. 1991. Molecular cloning of three cDNAs that encode cysteine proteinases in the digestive gland of the American lobster (Homarus americanus). FEBS Lett 292:115-120.

Le Boulay C, Van Wormhoudt A, Sellos D. 1995. Molecular cloning and sequencing of two cDNAs encoding cathepsin L-related cysteine proteinases in the nervous system and in the stomach of the Norway lobster (Nephrops norvegicus). Comp Biochem Physiol 111B:353-359.

Lehnert SA, Johnson SE. 2002. Expression of hemocyanin and digestive enzyme messenger RNAs in the hepatopancreas of the Black Tiger Shrimp Penaeus monodon. Comp Biochem Physiol 133B:163-171.

Le Vay L, Jones DA, Puello-Cruz AC, Sangha RS, Ngamphongsai C. 2001. Digestion in relation to feeding strategies exhibited by crustacean larvae. Comp Biochem Physiol 128A:623-630.

Maeda-Martínez AM, Obregón-Barboza V, Navarrete del Torro MA, Obregón-Barboza H, García-Carreño FL. 2000. Trypsin-like enzymes from two morphotypes of the 'living fossil' Triops (Crustacea: Branchiopoda: Notostraca). Comp Biochem Physiol 126B:317-323.

Neurath H. 1984. Evolution of proteolytic enzymes. Science 224:350-356

Pan BS, Lan CC, Hung TY. 1991. Changes in composition and proteolytic enzyme activities of Artemia during early development. Comp Biochem Physiol 100A:725-730.

Pfleiderer G, Zwilling R. 1972. Die molekulare Evolution proteolytischer Enzyme. Naturwissenschaften 59:396-405.

Stauffer C. 1989. Effect of $\mathrm{pH}$ on activity. In: Van Nostrand Reinhold, editor. Enzyme assay for food scientists. New York: AVI Press. p 61-76.

Sudaryono A, Tsvetnenko E, Evans LH. 1999. Evaluation of potential of lupin meal as an alternative to fish meal in juvenile Penaeus monodon diets. Aquacult Nutr 5:277-285.

Teschke M, Saborowski R. 2005. Cysteine proteinases substitute for serine proteinases in the midgut gland of Crangon crangon and Crangon allmani (Decapoda: Caridea). J Exp Mar Biol Ecol 316:213-229.

Vonk HJ, Western JRH. 1984. Invertebrate proteinases. In: Vonk HJ, Western JRH, editors. Comparative biochemistry and physiology of enzymatic digestion. London: Academic Press. p 184-254.

Yang Y, Xie S, Cui Y, Lei W, Zhu X, Yang Y, Yu Y. 2004. Effect of replacement of dietary fish meal by meat and bone meal and poultry by-product meal on growth and feed utilization of gibel carp, Carassius auratus gibelio. Aquacult Nutr 10: 289-294.

Zar JH. 1984. Biostatistical analysis. Englewood Cliffs, NJ: Prentice-Hall. 